\title{
Phylogenetic of sago palm (Metroxylon sagu) and others monocotyledon based on mitochondrial nad 2 gene markers
}

\author{
BARAHIMA ABBAS ${ }^{1,2, \boldsymbol{v}}$, IHWAN TJOLLI ${ }^{1}$, MUHAMMAD DAILAMI $^{3}$, MUNARTI $^{4}$ \\ ${ }^{1}$ Faculty of Agriculture, Universitas Papua. Jl. Gunung Salju, Amban, Manokwari 98314, West Papua, Indonesia. `email: b.abbas@unipa.ac.id \\ ${ }^{2}$ Graduate Program, Universitas Papua. Jl. Gunung Salju, Amban, Manokwari 98314, West Papua, Indonesia \\ ${ }^{3}$ Faculty of Marine and Fisheries, Universitas Brawijaya. Jl. Veteran No. 16, Malang 65145, East Java, Indonesia \\ ${ }^{4}$ Faculty of Teacher Training and Education Science, Universitas Pakuan. J1. Pakuan, Bogor 16143, West Java, Indonesia
}

Manuscript received: 15 June 2019. Revision accepted: 22 July 2019

\begin{abstract}
Abbas B, Tjolli I, Dailami M, Munarti. 2019. Phylogenetic of sago palm (Metroxylon sagu) and others monocotyledon based on mitochondrial nad2 gene markers. Biodiversitas 20: 2249-2256. Sago palm forest and sago palm semi cultivated are found in the Papua islands as well as Ambon and Seram islands. The diversity center of sago palm is found in the Papua Islands. The objectives of this study are revealed sequence DNA mitochondrial associated with nad2 genes in sago palm accessions and molecular phylogenetic of sago palm and other monocotyledon plants. Plant materials used in the studies were derived from Sago Research Center (SRC) and sequencing and other monocotyledon were retrieved from the GenBank, NCBI accessions. Young fresh leaflets were derived from the experimental field of SRC and DNA extraction by following the procedure of Plant Genomic DNA Mini Kit and then PCR performed by using nad2 primer sets. Thereafter, DNA PCR product was sequenced by Macrogen Inc., Seoul, Korea. Sequences of nad 2 genes in sago palm accessions from Papua, Indonesia were registered by GenBank NCBI for further used in the future as biological authenticity from the certain location. Mitochondrial DNA sequences associated with nad2 genes in the genome of sago palm were shown no differences among sago palm accessions. Molecular phylogenetic of sago palm and others monocotyledon based on nad2 gene markers showed the sago palm and others monocotyledon incorporated into two major clades and five subclades. Sago palm, coconut, and date palm were described as close related and being in the same subclades.
\end{abstract}

Keywords: Mitochondrial, monocotyledon, nad2 gene, phylogenetic, sago palm

\section{INTRODUCTION}

Sago palm (Metroxylon sagu Rottb.) is found growing in the countries of Southeast Asia, Oceania, and the Pacific Islands at latitude $10^{\circ}$ South and $10^{\circ}$ North (Ishizuka et al. 1996), longitude $90^{\circ}$ to $180^{\circ}$ East, and altitude up to 1000 meters above sea level (Bintoro 2011). Sago palm forest and sago palm semi cultivated is found in the Papua islands as well as Ambon and Seram islands (Flach 1997; Abbas et al. 2014). Schuiling (1995) reveals the diversity center of sago palm found in the Moluccas and New Guinea. Flach (1997) reported that New Guinea (Papua-Indonesia and Papua New Guinea) as a center of diversity of sago palm. McClatchey et al. (2005) believe that sago palm endemic in Papua-Indonesia, New Guinea, New Britain, and the islands of the Moluccas. Sago palm found widespread in Southeast Asia, Melanesia, and some islands in Micronesia and Polynesia (McClatchey et al. 2005). Estimation 1.25 million hectares of sago forest and 148,000 hectares of sago palm plantations located in Indonesia. Papua Province and West Papua province, Indonesia territorial is estimated 1.2 million hectares of sago palm forest and 14,000 hectares of sago palm plantations (Flach 1997). Recently reported the sago palm areal widely distributed in Papua Province Indonesia territorial with it has 4.749 .325 hectares and 510.213 hectares in the West Papua Province, Indonesia (Bintoro 2015) and mostly sago palm growth in the inundated areas and semi inundated areas (Yater et al.
2019). Distribution of sago palm area in Indonesia is uneven. Papua Island, Indonesia territorial has the largest sago palm areas compared with other islands in Indonesia. Abbas et al. (2014) reported that $92 \%$ of sago palm area is located on the island of Papua and $8 \%$ of sago palm area is in the other islands in Indonesia.

Morphological characters of sago palm in Indonesia were reported high variation. Riyanto et al. (2018) revealed that sago palm seedling showed in high variations based on morphology and genetic using RAPD markers. Abbas (2018) reported that sago palm high variation based on molecular markers, such as RAPD markers, Waxy gene markers, and rpl1671, NTCP21, and NTCP22 of cpDNA markers. Furthermore, sago palm reported also variation in the ability to result carbohydrates. The ability of sago palm to produce carbohydrates is higher than other starchproducing plants. Karim et al. (2008) reported that sago starch production was 3 to 4 times higher than rice, maize or wheat production and 17 times higher than cassava production. Bujang (2008) reported that the yield potential of sago palm in Malaysia is reached 25 tons of starch ha ${ }^{-1}$ year $^{-1}$. The dried starch produced by sago palm was reported between 200-400 kg tree ${ }^{-1}$ (Dewi et al. 2016). Sago palm encountered in Sentani, Papua, Indonesia with local names Para, Panne, Yebha, Wanny sequentially have average production capability of $674 \mathrm{~kg}, 576 \mathrm{~kg}, 512 \mathrm{~kg}$, $491 \mathrm{~kg}$ tree $^{-1}$ (Yamamoto 2011). Starch production of 
others sago palm varieties reaches 49 tons of starch ha-1 in Indonesia (Abbas 2015; Abbas 2018).

Higher plants including sago plants have three genetic information centers namely the nuclear genomes, chloroplast genomes, and mitochondrial genomes. The function of mitochondria in higher plants is as an energygenerating organelle in the cell. Mitochondrial (mt) genomes are organelles that have DNA in a circular shape and maternally inherited (Castro et al. 1998) with a size around 222 to $773 \mathrm{~kb}$ for angiosperm (Kitazaki and Kubo 2010). The composition of $\mathrm{mt}$ genome was not influenced by the presence of crosses pollination. Changes mitochondrial DNAs (mtDNA) in the plant genome were reported that caused by the evolution in a long time, approximately 10,000 to100,000 years (Mower et al. 2007). Pervaiz et al. (2015) reported that the mt genome among Prunus species has a high conservative level. Genetic differentiation occurs in very small amounts in the maternally inherited marker such as mtDNA and cpDNA markers (Petit et al. 2005). The size of the plant mitochondrial genome varies from $200 \mathrm{kbp}$ to $2,000 \mathrm{kbp}$ (Morley and Nielsen 2017). Mitochondrial genomes undergo very low mutation processes (Christensen 2013) so it is good to use as a molecular marker for reveling phylogenetic of sago palm and others monocotyledon. The objectives of this study were to explore nucleotide sequence of nad2 gene associated in the genome of sago palm and reveled phylogenetic of sago accessions and others monocotyledon.

\section{MATERIALS AND METHODS}

\section{Plant materials}

Plant materials used in the studies were derived from several regions in Papua that has been collected by the Sago Palm Research Center (SRC) University of Papua (UNIPA) and others monocotyledon plant were retrieved from the NCBI GenBank accessions. Leaf samples were taken from accessions of sago palm in a growth russet stage. Accession name is not based on its local name because it is confusing. The Accession names are SP001, SP002, SP003, SP004, SP005, SP006, SP007, SP008, SP009, SP010, and SP011. Young leaf samples of sago palm accessions were preserved using silica gel in a zip lock plastic. The sago palm sample was used this study the same as were used Abbas et al. (2015) and Abbas et al. (2017).

\section{DNA extraction}

DNA extraction was done by following the procedure of Plant Genomic DNA Mini Kit (Geneaid 2012). The outlines of DNA extraction using Geneaid protocols are tissue dissociation, lysis, DNA binding, wash, and DNA elution. Tissue dissociation was done by grind the sample to a fine powder. As much as $20 \mathrm{mg}$ fine powder of the sample was transfer to a $1.5 \mathrm{ml}$ microcentrifuge tube, then following step 2, step 3, step 4, and step 5 in the protocols. The genomic DNAs were extracted it is stored at-20 ${ }^{\circ} \mathrm{C}$ freezer until ready used.

\section{PCR and sequencing}

Design of nad2 primer sequences was used in this study it is adopted from Duminil et al. (2002) and synthesize by Genetica Science Company. The Primer sequences used for amplified mitochondrial which association with nad2 gene in the sago palm genome as follows: forward 5, TTC ATA TAG AAT CCA TGT CC 3'and reverse 5' CTA TTT GTT CTT CGC CGC TT 3'. PCR mixtures and cycles condition were followed by $25 \mathrm{ml}$ total volume that contains: $1 \mathrm{x}$ PCR buffer contained $1.5 \mathrm{mM} \mathrm{MgCl} 2$ (KAPA 2G Robust HotStart), $10 \mathrm{mM}$ dNTP mix, $10 \mu \mathrm{M}$ of forward and reverse primer, 1 x KAPA Enhancer, 0.5 U KAPA 2G Robust Hotstar polymerases, and $10 \mathrm{ng}$ genomic DNA. PCR cycles condition as follows: initial denaturation for 15 seconds at $94^{\circ} \mathrm{C}$, followed by 30 cycles of denaturation for 30 seconds at $94^{\circ} \mathrm{C}$, annealing for 30 seconds at $50^{\circ} \mathrm{C}$, for 45 seconds extension at $72^{\circ} \mathrm{C}$. PCR amplification fragments were separated on $1 \%$ agarose gels by electrophoresis, staining was done using Ethidium Bromide and visualization by using UV illumination apparatus. Sequencing and purification of DNA PCR product were performed by Macrogen Inc., Seoul, Korea.

\section{Data analysis}

DNA sequences in the form of electropherogram were edited and checked to obtain correct DNA sequence. Editing and proofreading sequences were performed by matching the peak color of the electropherogram to the sequence of nucleotides produced using Molecular Evolutionary Genetics Analysis (MEGA) 5.0.5 software (Tamura et al. 2011). Each sequence in this study was obtained from the forward and reverse sequences of each sample. The editing result of a nucleotide sequence is stored in the Fasta file format. Cluster alignment was performed based on Clustal W with MEGA 5.0.5 software. Comparison of sample sequences with GenBank database (NCBI) is done using Basic Local Alignment Search Tools (BLAST) available on the National Center for Biotechnology Information (NCBI) web (Zhang et al. 2000; Morgulis et al. 2008). Phylogenetic construction of sago palm accession and other related plant-based on nad 2 gene was calculated by using Mega 6 software (Tamura et al. 2013). Outgroup was performed by using the UPGMA method (Sneath and Sokal (1973) and the evolutionary distances were computed using the Maximum Composite Likelihood method (Tamura et al. 2004). The certain species were choose based on the potential of resulting large amount carbohydrate of monocots plant.

\section{RESULTS AND DISCUSSION}

\section{Nucleotide sequence of $\mathbf{n a d} 2$ genes}

Forward and reverse sequences nad2 genes of sago palm were performed by Macrogen Inc., Seoul, Korea. Alignments of the mitochondrial sequences associated with nad2 genes of sago palm accessions were presented in Figure 1. All of accessions has the number of sequences as much as 1304 base and just showed 61 bases in Figure 1 . The complete sequences of sago palm accessions used in 
this study were prepared and accessible by retrieved in the GenBank, NCBI. Mitochondrial sequences associated with nad2 genes in the sago palm accessions showed that no differences event through morphological differences (Table 1). Blast analyses of sago palm and other monocotyledon were presented in Table 2 . The nucleotide sequences nad 2 genes of sago palm were registered in the GenBank, NCBI with the accession sequence number KY849955.1, KY849956.1，KY849957.1，KY849958.1，KY849959.1, KY849960.1, KY849961.1, and KY849962.1. Actually, we performed eleven accessions for sequencing of sago palm that representative of morphological differentiation, but other three accessions were figured out that their sequence contaminated. The peaks of electropherograms of those three accessions ware not clear separation. The nad 2 gene sequences of eight sago palm accessions showed no differences event the morphological different (Abbas et al. 2017). Based on investigation of mitochondrial genome in the previous studied such as beet showed that plant mitochondrial genome possesses a low mutation rate, a little compactness, large size, and high rearrange structure (Darracq et al. 2011). Furthermore, it was reported that $\mathrm{mt}$ genome of plants have a mechanism of base excision repair pathway (Boesch et al. 2009) so that the nucleotide structure is very conservative, even though morphologically different. Morphological differences were probably controlled by multigenic function which associated in the nucleus and mitochondrial, or chloroplast genomes, such as young petiole color, spine types, and spear color. Genes associated with mitochondrial genome such as nad2 gene were generally known their function as energy regulation in biological metabolism. Chen et al. (2017) reported that the mitochondria are responsible as primary source of cellular energy for growth, development, and reproduction of organism. The registration number of sago palm sequences associated with mitochondrial nad2 gene as follows: (i) KY849955.1Metroxylon sagu accession 1 NADH dehydrogenase subunit 2 (nad2) gene, intron; mitochondrial; (ii) KY849956.1Metroxylon sagu accession 2 NADH dehydrogenase subunit 2 (nad2) gene, intron; mitochondrial; (iii) KY849957.1Metroxylon sagu accession 3 NADH dehydrogenase subunit 2 (nad2) gene, intron; mitochondrial; (iv) KY849958.1Metroxylon sagu accession 4 NADH dehydrogenase subunit 2 (nad2) gene, intron; mitochondrial; (v) KY849959.1Metroxylon sagu accession 5 NADH dehydrogenase subunit 2 (nad2) gene, intron; mitochondrial; (vi) KY849960.1Metroxylon sagu accession 6 NADH dehydrogenase subunit 2 (nad2) gene, intron; mitochondrial; (vii) KY849961.1Metroxylon sagu accession $7 \mathrm{NADH}$ dehydrogenase subunit 2 (nad2) gene, intron; mitochondrial; (viii) KY849962.1Metroxylon sagu accession $8 \mathrm{NADH}$ dehydrogenase subunit 2 (nad2) gene, intron; mitochondrial.

\section{Basic local Alignment Search Tool (BLAST)}

Comparison the DNA sequence homology of sago palm accessions and other others monocotyledon in the NCBI GenBank DNA database were performed by BLAST analysis (Table 2). The results of BLAST analysis showed that sago palm accessions and other related plant have high similarity. The Maximum score range from 1274 to 2374 indicated that the largest value of the plant genus is the highest similarity of sago palm. The Query cover for all species used has value $100 \%$, this indicated high degree of alignment to BLAST sequences. The E-value of 0.0 indicates the number of alignments with scores equivalent to the database and better quality of the alignment BLAST search. The DNA sequences have high similarity if the query cover is closed to $100 \%$ and the E-value is closed 0.0 (Claverie and Notredame 2003). The identity for 51 plant samples have value in the range of $85 \%$ to $99 \%$. The smallest of the identity value is Butomus umbelatus and the highest of the identity value is Cocos nucifera and Phoenix dactilifera. These indicated that $C$. nucifera and $P$. dactilifera is the highest similarity with sago palm based on mitochondrial nad2 gene.

\section{Genetic distance of sago palm and others monocotyledon}

Genetic distance of sago palm accessions and related plant from several families based on $n a d 2$ gene markers showed range from 0.000 to 0.171 (Table 3). Sago palm accessions have calculated no differences between the others based on nad2 gene markers with molecular distances 0.000. In the reverse, the largest genetic distances were calculated between species Triticum aestivum and Butomus umbellatus with genetic distance value 0.171 . Reverse of that overall sago palm accessions used being in one species of is a Metroxylon sagu. The species closer to sago palm is Cocos nucifera and following Phoenix dactylifera with genetic distances value of 0.003 and 0.006 respectively (Table 2).

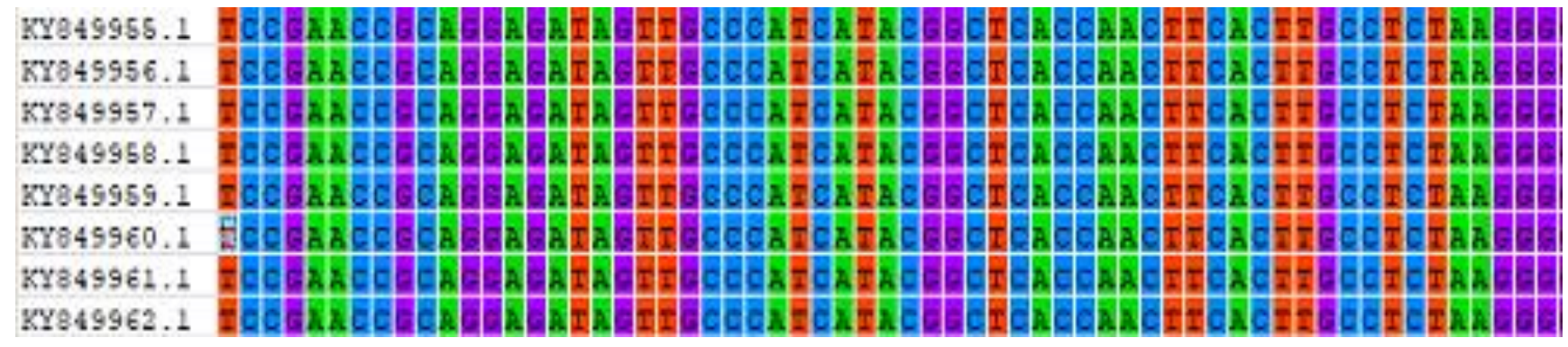

Figure 1. Alignment of nucleotide sequence of eight sago palm accessions 
Table 1. Morphological characteristic in the russet stages of sago palm accessions from Papua, Indonesia

\begin{tabular}{lllllll}
\hline \multirow{2}{*}{ Accession } & \multicolumn{5}{c}{ Morphological characteristic } \\
\cline { 2 - 7 } & Spine type & Spear color & Young leaf color & Leaf color & Young petiole color & Petiole \\
\hline SP001 & Spiny & RHS67A & RHS67A & RHS142A & RHS67A & RHS154A \\
SP002 & Spineless & RHS67A & RHS67A & RHS142A & RHS67A & RHS142A \\
SP003 & Spineless & RHS142A & RHS150C & RHS142A & Strips 154B \& 153D & Strips RHS150C \& RHS33D \\
SP004 & Spineless & RHS142A & RHS150C & RHS142A & 150C & 142A \\
SP005 & Spineless & RHS142A & RHS150C & RHS142A & 150C & 142A \\
SP006 & Spineless & RHS142A & RHS150C & RHS142A & Strips 154B \& 153D & Strips RHS150C \& RHS33D \\
SP007 & Spineless & RHS142A & RHS150C & RHS142A & RHS67A & 154A \\
SP008 & Spineless & RHS67A & RHS67A & RHS142A & RHS67A & 154A \\
\hline
\end{tabular}

Notes: RHS67A is strong purplish-red, RHS142A is strong yellowish-green, RHS154A is vivid yellowish-green, RHS150C is brilliant yellowish-green, RHS33D is Moderate yellowish pink, RHS154B is brilliant yellowish-green, RHS153D is strong yellow

Table 2. Blast analysis of sago palm and others monocotyledon based on nad2 genes

\begin{tabular}{|c|c|c|c|c|c|}
\hline Species name & Max. score & Query cover \% & E-value & Identity \% & Accession ID \\
\hline Cocos nucifera & 2374 & 100 & 0.0 & 99 & KX028885.1 \\
\hline Phoenix dactylifera & 2370 & 100 & 0.0 & 99 & JN375330.1 \\
\hline Ferrocalamus rimosivaginus & 2170 & 100 & 0.0 & 97 & JN120789.1 \\
\hline Ferrocalamus rimosivaginus & 2170 & 100 & 0.0 & 97 & JQ235171.1 \\
\hline Bambusa oldhamii & 2156 & 100 & 0.0 & 97 & EU365401.1 \\
\hline Triticum aestivum & 2159 & 100 & 0.0 & 97 & GU985444.1 \\
\hline Hordeum vulgare & 2154 & 100 & 0.0 & 96 & AP017301.1 \\
\hline Hordeum vulgare & 2154 & 100 & 0.0 & 96 & AP017300.1 \\
\hline Lolium perenne & 2146 & 100 & 0.0 & 96 & JX999996.1 \\
\hline Saccharum officinarum & 2134 & 100 & 0.0 & 96 & LC107875.1 \\
\hline Aegilops speltoides & 2126 & 100 & 0.0 & 96 & AP013107.1 \\
\hline Triticum timopheevii & 2126 & 100 & 0.0 & 96 & AP013106.1 \\
\hline Aegilops speltoides & 2126 & 100 & 0.0 & 96 & AP013107.1 \\
\hline Triticum timopheevii & 2126 & 100 & 0.0 & 96 & AP013106.1 \\
\hline Triticum aestivum & 2126 & 100 & 0.0 & 96 & EU534409.1 \\
\hline Triticum aestivum & 2126 & 100 & 0.0 & 96 & AP008982.1 \\
\hline Sorgum bicolor & 2128 & 100 & 0.0 & 96 & DQ984518.1 \\
\hline Oryza minuta & 2109 & 100 & 0.0 & 96 & KU176938.1 \\
\hline Oryza sativa Indica Group & 2098 & 100 & 0.0 & 96 & AP017386.1 \\
\hline Oryza rufipogon & 2098 & 100 & 0.0 & 96 & AP012528.1 \\
\hline Oryza sativa Indica Group & 2098 & 100 & 0.0 & 96 & JN861112.1 \\
\hline Oryza sativa Indica Group & 2098 & 100 & 0.0 & 96 & JN861111.1 \\
\hline Oryza sativa Indica Group & 2098 & 100 & 0.0 & 96 & JF281154.1 \\
\hline Oryza sativa Indica Group & 2098 & 100 & 0.0 & 96 & JF281153.1 \\
\hline Oryza sativa Indica Group & 2098 & 100 & 0.0 & 96 & AP011077.1 \\
\hline Oryza rufipogon & 2098 & 100 & 0.0 & 96 & AP011076.1 \\
\hline Oryza sativa Japonlca & 2098 & 100 & 0.0 & 96 & BA000029.3 \\
\hline Oryza sativa & 2098 & 100 & 0.0 & 96 & DQ167400.1 \\
\hline Oryza sativa & 2098 & 100 & 0.0 & 96 & DQ 167807.1 \\
\hline Orvza sativa & 2098 & 100 & 0.0 & 96 & DQ 167399.1 \\
\hline orvza sativa Japonica Group & 2093 & 100 & 0.0 & 96 & AP014957.1 \\
\hline Oryza sativa Jaoonica Group & 2093 & 100 & 0.0 & 96 & AP003280.2 \\
\hline Oryza rufipogon & 2091 & 100 & 0.0 & 96 & $\mathrm{AP} 012527.1$ \\
\hline Triticum aestivum & 2076 & 100 & 0.0 & 96 & Y14434.1 \\
\hline Tripsacum dactyloides & 2073 & 100 & 0.0 & 96 & DQ984517.1 \\
\hline Zea perennis & 2073 & 100 & 0.0 & 95 & DQ645538.1 \\
\hline Zea luxurians & 1993 & 100 & 0.0 & 95 & DQ645537.1 \\
\hline Zea mays subsp mays genotype CMS-S & 1989 & 100 & 0.0 & 94 & DQ490951.2 \\
\hline Zea mays parviglumis & 1989 & 100 & 0.0 & 94 & DQ645539.1 \\
\hline Zea mays subsp mays genotype CMS-C & 1989 & 100 & 0.0 & 94 & DQ645536.1 \\
\hline Zea mays subsp mays genotype CMS-T & 1989 & 100 & 0.0 & 94 & DQ490952.1 \\
\hline Zea mays subsp mays genotype male-fertile & 1989 & 100 & 0.0 & 94 & NC_007982.1 \\
\hline Zea mavs isolate SM10 & 1986 & 100 & 0.0 & 94 & KY018916.1 \\
\hline Scheuchzeria sp. & 1421 & 100 & 0.0 & 87 & KX363631.1 \\
\hline Butomus umbellatus & 1274 & 100 & 0.0 & 85 & KC208619.1 \\
\hline
\end{tabular}




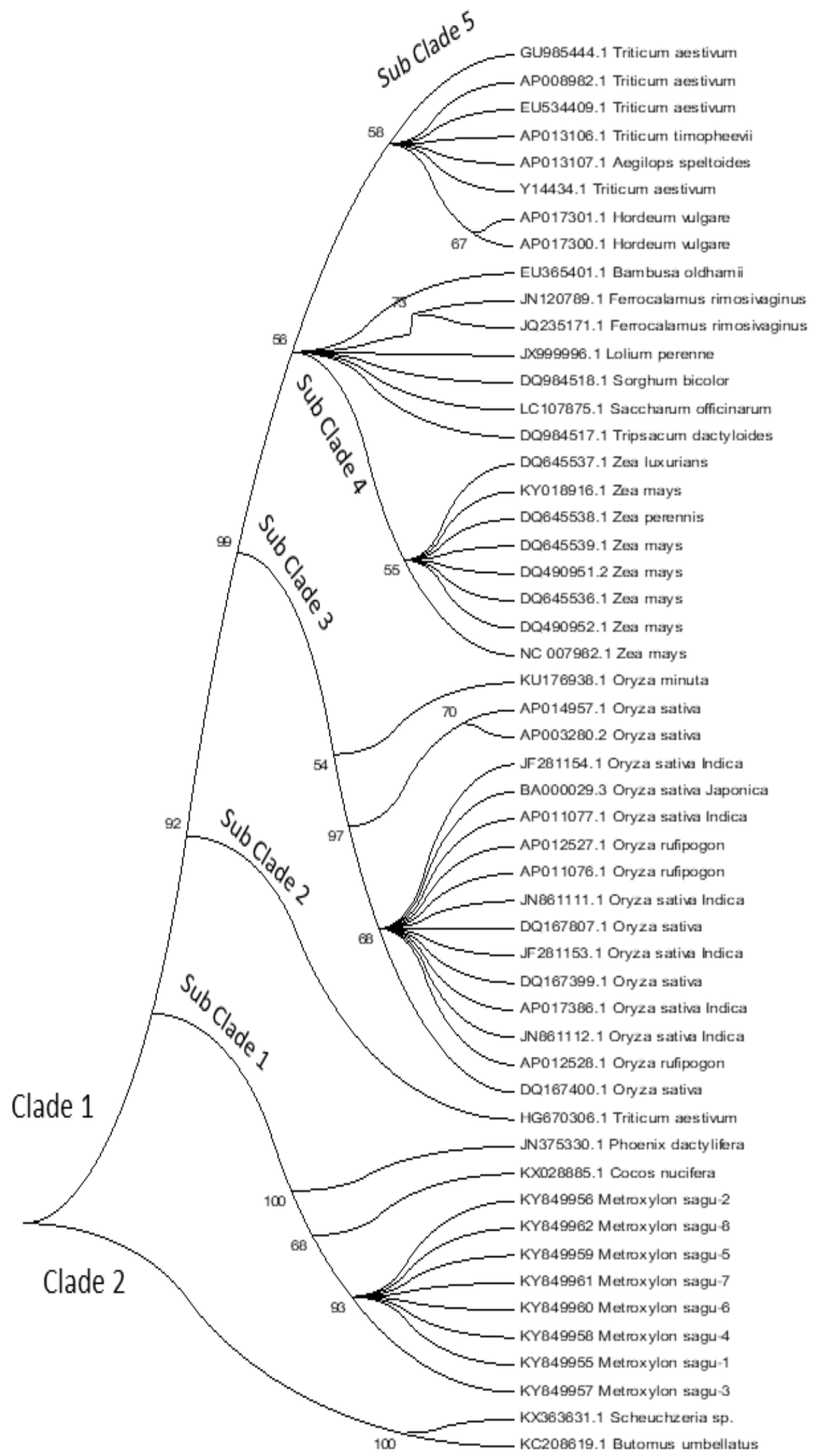

Figure 2. Phylogenetic construction of sago palm accession and related plant species based on nad2 gene markers 
Table 3. Genetic distance of sago palm accessions and related other plant producing carbohydrate

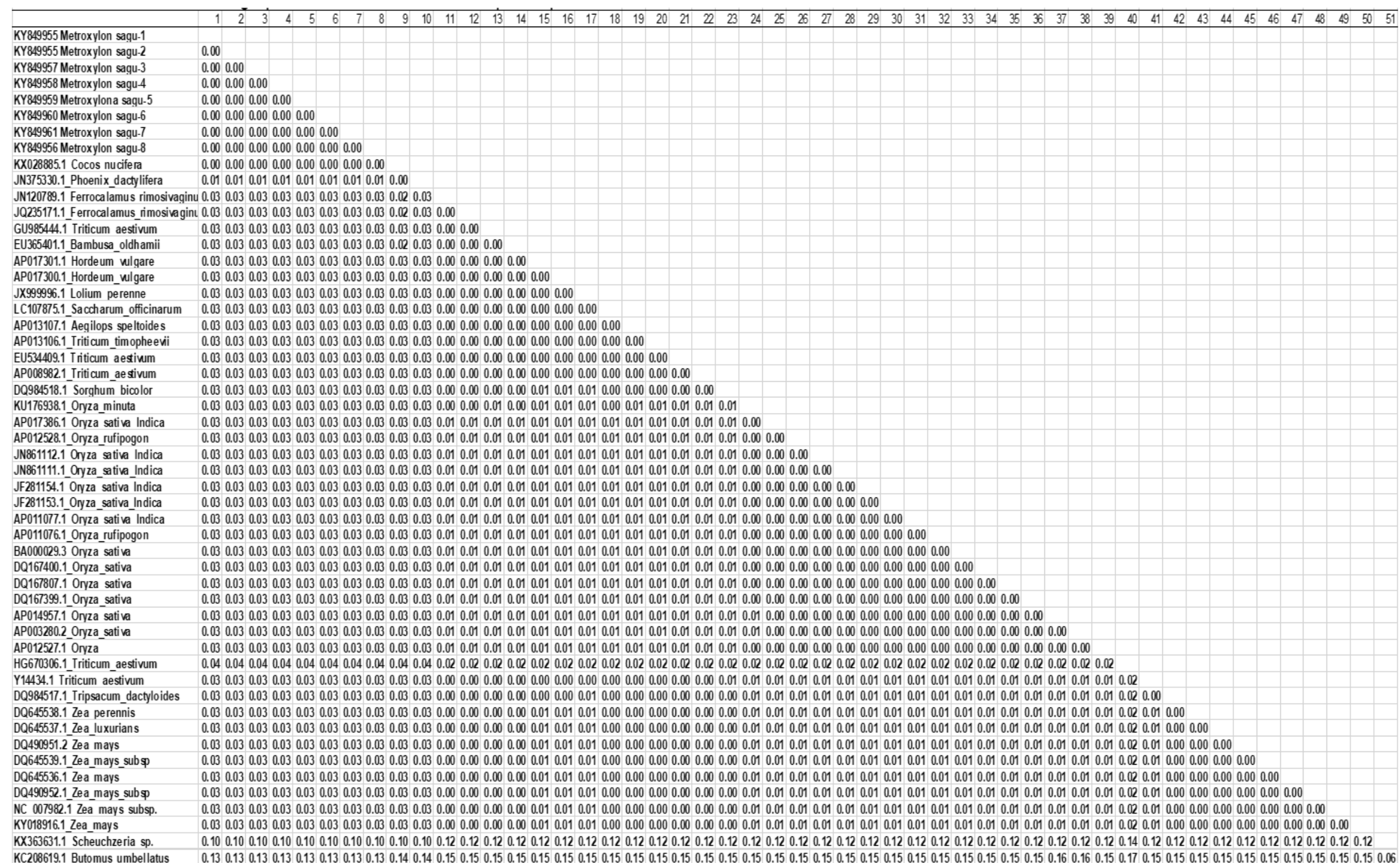


Metroxylon sagu, C. nucifera, and P. dactylifera are being in the group of palm tree family (Arecaceae), so hierarchical closed each other. Otherwise, it was reported that among sago palm accessions were calculated differently by using cpDNA gene marker (Abbas et al. 2010). The use of different molecular markers might result in different result, even though in the same plant genome object. Touzet and Delph (2009) reported that mitochondrial cytochrome b (cob) and cytochrome oxidase (cox1) was very little until no difference in mitochondrial nucleotide sequences in the hermaphroditic such as Silene scouleri, $S$. virginica, $S$. noctiflora and dioecious suc as $S$. latifolia, S. dioica, and S. diclinis, whereas gynodioecious such as $S$. vulgaris, $S$. acaulis, and $S$. nutans found many haplotypes based on mitochondrial DNA which means there are many differences in the arrangement of mitochondrial DNA. Sago palm is a hermaphroditic plant that it might cause their mitochondrial DNA sequence no differences among accessions based on nad2 gene marker. Barr et al. (2007) were reported that the mitochondrial plant is possessing low substitution rates and no recombination.

\section{Phylogenetic of sago palm and others monocotyledon}

Phylogenetic of sago palm and others monocotyledon that potentially produce large amount carbohydrate based on $\operatorname{nad} 2$ gene markers showed that the individual sample incorporated into two major clades. Clade 1 consist of five subclades and no subclade at clade 2. In cladistics or phylogenetics of clade 2 were determined an outgroup plant. Both plants of clade 2 are being monocotyledon plants but do not correlate produced large amount carbohydrate. All of sago palm accessions are being in the same subclade in the clade 1 , not separated to the other brunch of phylogenetic. Sago palm, coconut, and date palm are being in the same subclade at clade 1. Cereal plants that were known produce a lot of carbohydrates such as wheat, rice, and corn are being in the position of cluster 2 and flowering plants are being in the cluster 3 (Figure 2). In the previous studies of sago palm were reported that sago palm in the forest and in the semi cultivated have high diversity and divided into several clusters based on molecular marker of Waxy gene marker (Abbas et al. 2007; Abbas and Ehara 2012), RAPD marker (Abbas et al. 2009; Abbas et al. 2017; Abbas 2017). Sago palm accessions were in the same clusters of palm family that producing large amount of carbohydrates and other clusters are cereal plant and flowering plant. nad2 gene might be related to energy resources for accumulating starch in the stained part of plant. The NAD and NADP pyridine nucleotide pools were known to play critical roles for regulating energyproducing in the catabolic process (Blacker and Duchen 2016).

In conclusions, Sequences of nad2 genes in sago palm accessions from Papua, Indonesia were registered into GenBank NCBI for further used in the future as biological authenticity from the certain location. the study indicated that mitochondrial DNA sequences associated with nad2 genes in the genome of sago palm were shown no differences among accessions. Molecular phylogenetic of sago palm and others monocotyledon based on nad2 gene markers showed the sago palm and related plant incorporated into two major clades and five subclades. Sago palm, coconut, and date palm were described as closely related and being in the same subclades.

\section{ACKNOWLEDGEMENTS}

The research was financially funded by the Directorate General Strengthen Research and Development Republic Indonesia with Project title "Transformation of invention based on sago palm to become innovation for entrepreneurship orientation in order to accelerate food competitiveness and independent of the Nation" contract No.198/SP2H/LT/DRPM/2019. Authors thank the Research Development Project Manager.

\section{REFERENCES}

Abbas B, Bintoro MH, Sudarsono, Surahman M, Ehara H. 2009. Genetic relationship of sago palm (Metroxylon sagu Rottb.) in Indonesia based on RAPD markers. Biodiversitas 10 (4): 168-174.

Abbas B, Ehara H. 2012. Assessment genetic variation and relationship of sago palm (Metroxylon sagu Rottb.) in Indonesia based on specific expression gene (Wx genes) markers. Afr J Plant Sci 6 (12): 314-320.

Abbas B, Listyorini FH, Munarti. 2015. Genetic diversity of eleven sago palm accessions from SRC's germplasm based on mitochondrial atp6-2 gene and intron. The $12^{\text {th }}$ International Sago Symposium, Rikkyo University, Tokyo, Japan, $15-17^{\text {th }}$ September 2015. [Indonesian]

Abbas B, Paisey EK, Bachri S, Edowai DN, Ehara H.2014. Genetic diversities of sago palm forest in South Sorong, West Papua, Indonesia based on RAPD markers. Conf Soc Sago Palm Stud 23: 31 32 .

Abbas B, Paisey EK, Dailami M, Munarti. 2017. Assessment of genetic arrangement of sago palm collection based on mitochondrial nad2 gene marker. Proceeding of the $13^{\text {th }}$ International sago Symposium, Kuching Sarawak, Malaysia, 2-6 Oktober 2017.

Abbas B, Rauf AW, Listyorini FH, Munarti. 2014. Brief description of aspects of biology, ecology, agronomy, and prospects for development of sago palm. Eur J Sci Res 120 (2): 221-229.

Abbas B, Renwarin Y, Bintoro MH, Sudarsono, Surahman M, Ehara H. 2010 Genetic diversity of sago palm in Indonesia based on chloroplast DNA (cpDNA) markers. Biodiversitas 11:112-117.

Abbas B. 2015. Sago commodity as a pillar of food sovereignty that needs to be managed and developed wisely as well as sustainably for community welfare. Scientific Oration for inauguration of Professor in the University of Papua, Manokwari. [Indonesian].

Abbas B. 2017. Dimensions of development sago commodities in the perspective of local resource-based development. Scientific Oration that presented at the Open Senate Meeting in the framework of Graduation of Master Program, Bachelor and Diploma, University of Papua. Manokwari. [Indonesian]

Abbas B. 2018. Sago palm genetic resource diversity in Indonesia. In: Ehara H, Toyoda Y, Johnson D. (eds) Sago Palm. Springer, Singapore.

Barr CM, Keller SR, Ingvarsson PK, Sloan DB, Taylor DR. 2007. Variation in mutation rate and polymorphism among mitochondrial gene of Silene vulgaris. Mol Biol Evol 24 (8): 1783-1791.

Bintoro HMHD, Pratama AJ. 2015. Transformation of sago to agroindustry plantation through development of Science Park. Bogor Agricultural University. Paper presented at Science Park Seminar in Manokwari, November 25, 2015. [Indonesian]

Bintoro MH. 2011. Progress of sago research in Indonesia. In: Siregar IZ, Sudaryanto T, Ehara H, Suwardi, Lubis I, Ardie SW (eds.) Sago for food security, bio-energy, and industry, from research to market. Proceeding of the 10 th International Sago. Symposium. IPB International Convention Center, Bogor, Indonesia, October 29-31, 2011. [Indonesian] 
Blacker TS, Duchen MR. 2016. Investigating mitochondrial redox state using NADH and NADPH autofluorescence. Free Radic Biol Med 100: 53-65.

Boesch P, Ibrahim N, Paulus F, Cosset A, Tarasenko V, Dietrich A. 2009. Plant mitochondria possess a short-patch base excision DNA repair pathway. Nucleic Acids Res 37 (17): 5690-5700.

Bujang K. 2008. Potential of bioenergy from the sago industries in Malaysia. Biotechnology 14: 1-8.

Castro JA, Picornel A, Ramon M. 1998. Mitochondrial DNA: a tool for population genetic studies. Intl Microb 1:327-332

Chen Z, Zhao N, Li S, Grover CE, Nie H, Wendel JF, Hua J. 2017. Plant mitochondrial genome evolution and cytoplasmic male sterility. Crit Rev Plant Sci 36 (1): 55-69.

Christensen AC. 2013. Plant mitochondrial genome evolution can be explained by DNA repair mechanisms. Genome Biol Evol 5 (6) 1079-1086.

Claverie J, Notredame C. 2003. Bioinformatics for dummies. Willey Publishing. Indianapolis, USA.

Darracq A, Varre JS, Drouard LM, Courseaux A, Castric V, Laprade PS, Oztas S, Lenoble P, Barbe B, Touzet P. 2011. Structural and content diversity of mitochondrial genome in beet: A comparative genomic analysis. Genome Biol Evol 3: 723-736

Dewi RK, Bintoro MH, Sudrajat. 2016. Karakter morfologi dan potensi produksi beberapa aksesi sagu (Metroxylon spp.) di Kabupaten Sorong Selatan, Papua Barat. J Agron Indonesia 44:91-97. [Indonesian]

Duminil J, Pomonge MH, Petit RJ. 2002. A set of 35 consensus primer pairs amplifying genes and introns of plant mitochondrial DNA. Mol Ecol Notes 2:428-430

Flach M. 1997. Sago Palm Metroxylon sagu Rottb. Promoting the Conservation and Used of Under-Utilized and Neglected Crops. 13 Institute of Plant Genetics and Crop Plant Research, Gatersleben/Internasional Plant Genetic Resources Institute (IPGRI), Rome, Italy

Ishizuka K, Hisajima S, Macer DRJ. 1996. Traditional technology for environmental conservation and sustainable development in the Asian-Pacific Region. Proceedings of UNESCO. University of Tsukuba, Japan.

Karim AA, Tie APL, Manan DMA, Zaidul ISM. 2008. Starch from the sago (Metroxylon sagu) palm tree-properties, prospects and challenges as a source for food and other uses. Compr Rev Food Sci Food Saf 7: 215-228.

Kitazaki K, Kubo T. 2010. Cost of having the largest mitochondria genome: Evolutionary mechanism of plant mitochondrial genome. J Bot. DOI: $10.1155 / 2010 / 620137$

McClatchey W, Manner HI, Elevitch CR. 2005. Metroxylon amicarum, M. paulcoxii, M. sagu, M. salomonense, M. vitiense, and $M$. warburgii (sago palm). Species Profiles for Pacific Island Agroforestry. Permanent Agriculture Resources-UH Press, Hawaii

Morgulis A, Coulouris G, Raytselis Y, Madden TL, Agarwala R, Schäffer AA. 2008. Database indexing for production MegaBLAST searches, Bioinformatics 24: 1757-1764.

Morley SA, Nielsen BL. 2017. Plant mitochondrial DNA. Front Biosci 1 (22): 1023-1032.

Mower JP, Tauzet P, Gummow J, Delph LF, Palmer JD. 2007. Extensive variation in synonymous substitution rates in mitochondrial genes of seed plants. BMC Evol Biol 7 (135): 1-14.

Pervaiz T, Sun X, Zhang Y, Tao R, Zhang J. 2015. Association between chloroplast and mitochondrial DNA sequences in Chinese Prunus genotypes (Prunus persica, Prunus domestica, and Prunus avium). BMC Plant Biol 15: 4. DOI 10.1186/s12870-014-0402-4

Petit RJ, Duminil J, Fineschi S, Hampe A, Salvini D, Vendramin GG. 2005. Comparative organization of chloroplast, mitochondrial, and nuclear diversity in plant populations. Mol Ecol 14: 689-701.

Riyanto R, Widodo I, Abbas B. 2018. Morphology, growth and genetic variations of sago palm (Metroxylon sagu) seedlings derived from seeds. Biodiversitas 19 (2): 602-608.

Schuiling DL. 1995. The variability of the sago palm and the need and possibilities for its conservation. In: Subhadrabandhu S, Sdoodee S (eds.). Fifth International Sago Symposium. Hat Yai, Songkhla, Thailand, 27-29 January 1994. ISHS Acta Hort 38 (9)..

Sneath PHA, Sokal RR. 1973. Numerical Taxonomy. Freeman. San Francisco.

Tamura K, Nei M, Kumar S. 2004. Prospects for inferring very large phylogenies by using the neighbor-joining method. Proc Natl Acad Sci USA 101 (30): 11030-11035.

Tamura K, Peterson D, Peterson N, Stecher G, Nei M, Kumar S. 2011. MEGA5: Molecular Evolutionary Genetics Analysis using maximum likelihood, evolutionary distance, and maximum parsimony methods. Mol Biol Evol 28: 2731-2739.

Tamura K, Stecher G, Peterson D, Filipski A, Kumar S. 2013. MEGA6: Molecular Evolutionary Genetics Analysis version 6.0. Mol Biol Evol 30: 2725-2729.

Touzet P, Delph LF. 2009. The effect of breeding system on polymorphism in mitochondrial genes of sine. Genetics 181:631-664

Yamamoto Y. 2011. State of the art sago research in Asia Pacific. Proceeding of the $10^{\text {th }}$ International Sago Symposium, October 29-30, 2011, Bogor, Indonesia.

Yater T, Tubur HW, Meliala C, Abbas B. 2019. Short communication: A comparative study of phenotypes and starch production in sago palm (Metroxylon sagu) growing naturally in temporarily inundated and non-inundated areas of South Sorong, Indonesia. Biodiversitas 20: 1121-1126.

Zhang Z, Schwartz S, Wagner L, Miller W. 2000. A greedy algorithm for aligning DNA sequences, J Comput Biol 20007 (1-2): 203-214. 